\title{
Diabetes-related mortality among Mexican Americans, Puerto Ricans, and Cuban Americans in the United States
}

\author{
Chrystal A. S. Smith ${ }^{1}$ and Elizabeth Barnett ${ }^{2}$
}

Suggested citation Smith CAS, Barnett E. Diabetes-related mortality among Mexican Americans, Puerto Ricans, and Cuban Americans in the United States. Rev Panam Salud Publica. 2005;18(6):381-7.

ABSTRACT Objectives. Hispanics are the most rapidly growing minority group in the United States, and Mexican Americans, Puerto Ricans and Cuban Americans are the three largest Hispanic subgroups. Among Hispanics, type 2 diabetes is the fifth leading cause of death. This paper examines diabetes-related mortality in Mexican Americans, Puerto Ricans, and Cuban Americans over 35 years of age in the United States during 1996 and 1997.

Methods. Using data from the National Vital Statistics System and the 1990 and 2000 censuses, we calculated age-adjusted and age-specific diabetes-related death rates for Mexican Americans, Puerto Ricans, and Cuban Americans over 35 years of age. Diabetes-related deaths were determined to be any death for which diabetes was coded as either the underlying or contributing cause of death.

Results. The diabetes-related mortality rate for Mexican Americans (251 per 100 000) and Puerto Ricans (204 deaths per 100 000) was twice as high as the diabetes-related mortality rate for Cuban Americans (101 deaths per 100 000). Cuban American decedents had the highest proportion of deaths with diabetes coded as the underlying cause of death (44\%). After diabetes, heart disease (31\%) followed by cancer ( $8 \%$ ) and stroke $(6 \%)$ were the most frequent primary underlying causes of diabetes-related deaths in all three ethnic groups.

Conclusion. Our analyses of these data demonstrate that diabetes-related mortality differed among Mexican Americans, Puerto Ricans and Cuban Americans more than 35 years of age in the United States in 1996 and 1997. Socioeconomic factors such as low educational attainment and low income may be factors that contributed to the disparities in these mortality rates for different subgroups. Further research is needed to update these findings and to investigate explanatory risk factors. Diversity among Hispanic subgroups has persisted in recent years and should be considered when health policies and services targeted at these populations are developed.

Key words Health status indicators; mortality; diabetes mellitus; Hispanic Americans; statistics and numerical data; epidemiology; socioeconomic factors.

Department of Anthropology, University of South Florida, Tampa, FL, United States of America. Send correspondence and reprint requests to Chrystal A. S. Smith, MAA, MPH, University of South Florida, Department of Anthropology, 4202 E. Fowler Ave., SOC107, Tampa, FL 33620-5375, United States of America; telephone: (813) 974 2138; fax: (813) 974 2668; e-mail: casmith5@mail.usf.edu
According to the 2000 census, approximately 35.3 million Hispanics re-

\footnotetext{
2 Department of Epidemiology and Biostatistics, College of Public Health, University of South Florida, Tampa, FL, United States.
}

side in the United States of America (1). The term "Hispanic" refers to several nationalities and ethnic groups of Latin American and Spanish-speaking Caribbean heritage (2). Hispanics are the largest ethnic minority group, 
comprising of $12.5 \%$ of the total population, a proportion slightly higher than that made up by African Americans $(12.3 \%)$. The three largest Hispanic subgroups are Mexican Americans (61\% of all Hispanics), Puerto Ricans (12\% of all Hispanics), and Cuban Americans (5\% of all Hispanics), with the remaining $22 \%$ of all Hispanics in the United States coming from all other Latin American and Caribbean countries.

Diabetes is a serious public health problem for Hispanics. In 1996, diabetes was ranked sixth among the 10 leading causes of death for Hispanics (3). From 1997 to 1999, diabetes was ranked fifth among the 10 leading causes of death for Hispanics (4-6). Type 2 diabetes is diagnosed in approximately $90 \%$ to $95 \%$ of all cases of diabetes (7). Hispanics are 1.5 to 1.9 times as likely to have diabetes as nonHispanic whites $(8,9)$. Moreover, Mexican Americans are twice as likely to have diabetes as non-Hispanic white adults (9-12).

Most previous research on Hispanic health issues has not examined specific ethnic subgroups. Although a few studies have examined general morbidity and mortality differentials among Hispanic subgroups, they did not conduct in-depth analyses of the diabetes mortality data for these subgroups (1316). Our study examined the diabetesrelated mortality data for Mexican Americans, Puerto Ricans, and Cuban Americans over 35 years of age in the United States for the years 1996 and 1997 to determine whether there were differences in mortality rates between these groups, and differences between the sociodemographic characteristics of these decedents. We focused on decedents over 35 years of age in order to capture the group most likely to suffer from adult-onset (type 2) diabetes. By analyzing the diabetes-related mortality data for the three largest Hispanic subgroups, we acknowledge that in each subgroup the sociocultural experience is different, and that this may influence their mortality rates.

Diabetes (particularly type 2 diabetes) is a complex syndrome that can be a direct cause of death and that can also contribute indirectly to deaths from other ailments, such as cardiovascular disease. Consequently, our inclusion of deaths for which diabetes was the contributing as well as underlying cause of death ensured that diabetes mortality was not underrepresented in our analysis.

\section{METHODS}

\section{Study population}

The study population comprised Mexican Americans, Puerto Ricans, and Cuban Americans over 35 years of age who resided in the United States at the time of their death in 1996 and 1997. The death data for this study were collected from death certificates where the ethnicity of the decedent was identified as Mexican American, Puerto Rican or Cuban by family members or by observation if a family member was not available. On the population census form as well on state death certificates, race is a separate category from ethnicity or ancestry so persons designated as "Hispanic" can be of any "race." The population data for this study were collected from the United States Bureau of the Census 1990 and 2000 decennial censuses of population and housing $(17,18)$. On standardized surveys, both censuses asked respondents to self-report their ethnicity. Respondents were asked if they were of Hispanic heritage; if they answered "yes" they were asked specifically if their ethnicity was Mexican American, Puerto Rican or Cuban $(17,18)$.

\section{Data sources}

The death certificate data for Mexican Americans, Puerto Ricans, and Cuban Americans over 35 years of age for the years 1996 and 1997 were collected from the National Vital Statistics System compiled by the National Center for Health Statistics (NCHS) (19). The following information was extracted from the death data tapes for each decedent: diabetes as the underlying or contributing cause of death, ethnicity (Mexican American, Puerto Rican and Cuban), age, gender, marital status, educational status, place of birth and state of residence.

Diabetes-related deaths were identified as those deaths for which diabetes was coded as the underlying or contributing cause of death (up to 20 conditions may be listed as a contributing cause of death). Diabetes is coded as 250 according to the International Classification of Diseases, ninth revision (ICD-9) (20). Diabetes as a contributing cause was included in the data set because the condition may contribute to underlying causes of death such as heart disease (ICD-9 codes 390-429) and stroke (ICD-9 codes 430-438) (8). As a result, diabetes is often recorded on the death certificate as a contributing cause for these diseases.

To obtain the population count for the denominator used to calculate the death rate, we calculated the age-, ethnicityand gender-specific intercensal estimates for 1996 and 1997 using data from the 1990 and 2000 United States Bureau of the Census decennial censuses $(17,18)$. To determine the population count for 1996 and 1997, the population change for each year between 1990 and 2000 was assumed to be constant. To calculate the population change for each year, the Mexican American, Puerto Rican, and Cuban population of 1990 was subtracted from the 2000 Mexican American, Puerto Rican, and Cuban populations respectively, and this difference was divided by 10 (accounting for the 10 years between the two censuses). The population change for each year was then added to the 1990 population to obtain the population estimates for the intercensal years.

\section{Calculation of diabetes-related death rates}

The age-adjusted mortality rates for diabetes-related deaths were calculated separately for Mexican Americans, Puerto Ricans, and Cuban Americans over 35 years of age in the United States during 1996 and 1997. The nu- 
merators were Mexican American, Puerto Rican, and Cuban deaths where diabetes was the underlying or contributing cause of death. The denominators were the population counts for 1996 and 1997. The data for the numerator and denominator were grouped into 10-year age groups: 35-44 years, 45-54 years, 55-64 years, 65-74 years, 75-84 years, and 85 years and older. The direct method of standardization was used to calculate age-adjusted death rates with the 2000 United States population as the standard.

\section{RESULTS}

\section{Characteristics of Mexican American, Puerto Rican, and Cuban American decedents}

In the years 1996 and 1997, diabetes was the underlying or contributing cause of death for 19563 Mexican Americans, Puerto Ricans, and Cuban Americans over 35 years of age. Of these decedents, approximately $77 \%$ (15 107) were Mexican Americans, 15\% (2 884) were Puerto Rican and 8\% (1572) were Cuban. The sociodemographic characteristics of this study population including median age, educational attainment, marital status of decedents by gender, and place of birth are presented in Table 1. Cuban American decedents had the highest level of educational attainment, while Mexican American decedents had the lowest level of educational attainment of the three ethnic groups. Regardless of ethnicity most of the decedents were married men, while widows made up the largest proportion of female decedents.

\section{Diabetes-related death rates}

Mexican American decedents had the highest age-adjusted rate of diabetesrelated mortality (251 per 100000 ), followed by Puerto Ricans (204 deaths per 100 000) and then Cuban Americans (101 deaths per 100 000) (Table 2). In all three Hispanic subgroups, men had higher age-adjusted rates of diabetes-

TABLE 1. Sociodemographic characteristics of Mexican American, Puerto Rican, and Cuban American decedents 35 years of age and older with cause of death reported as diabetes-related, 1996-1997

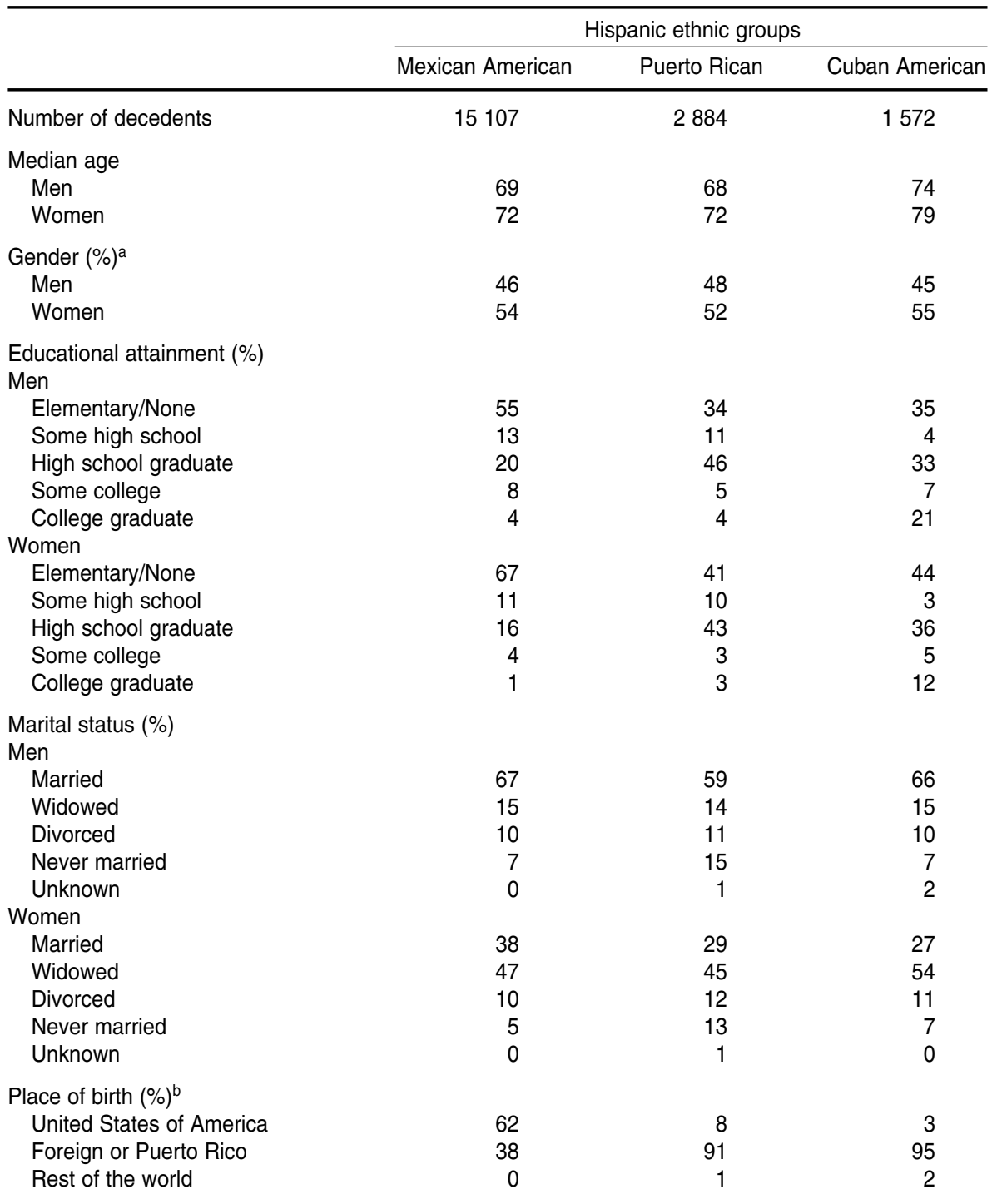

a Percentage and age have been rounded to the nearest whole number.

$\mathrm{b}$ The place of birth for most foreign-born Mexican Americans was Mexico. The place of birth for most Puerto Ricans was Puerto Rico. Most of the foreign-born Cuban Americans were born in Cuba.

related mortality than women (Table 2). Overall, Mexican Americans had the highest age-specific diabetes-related death rates, followed by Puerto Ricans, and then Cuban Americans (Table 3). Of the three ethnic groups, Cuban American decedents had the lowest age-specific diabetes-related death rates in every age group. The age-specific diabetes-related death rates for Puerto Rican decedents in the age groups 35 to
44 years and 45 to 54 years were the same as or higher than the death rates for Mexican decedents in the same age groups. Gender comparisons showed that Mexican American, Puerto Rican and Cuban American men had higher age-specific diabetes-related death rates than the women in their respective ethnic groups. As Mexican American, Puerto Rican and Cuban American decedents became older, their age- 
TABLE 2. Age-adjusted diabetes-related death rates per 100000 for Mexican Americans, Puerto Ricans, and Cuban Americans 35 years of age and older by gender and age, 1996-1997

\begin{tabular}{lc}
\hline Hispanic ethnic groups & Age-adjusted death rates \\
\hline Mexican American & \\
Total & 251 \\
Men & 263 \\
Women & 237 \\
Puerto Rican & \\
Total & \\
Men & 204 \\
Women & 216 \\
Cuban & 192 \\
Total & \\
Men & \\
Women & 101 \\
\end{tabular}

${ }^{a}$ Rates have been rounded to the nearest whole number.

specific diabetes-related death rates increased regardless of gender.

\section{Diabetes as the underlying or contributing cause of death}

Overall, Cuban Americans had the highest proportion of diabetes-related deaths for which diabetes was the underlying cause of death (44\%), followed by Puerto Ricans (39\%) and
Mexican Americans (37\%). In all three Hispanic subgroups, the proportion of diabetes-related deaths for which diabetes was recorded as the underlying cause of death was similar in men and women.

Our analysis found that after diabetes, heart disease (31\%) followed by cancer $(8 \%)$ and stroke $(6 \%)$ were the most frequent primary underlying causes of death in all diabetes-related deaths in both sexes in all three ethnic

TABLE 3. Age-specific diabetes-related death rates per 100000 for Mexican Americans, Puerto Ricans, and Cuban Americans 35 years of age and older by gender and age, 1996-1997

\begin{tabular}{|c|c|c|c|c|c|c|}
\hline Hispanic ethnic groups & $\begin{array}{l}35-44 \\
\text { years }\end{array}$ & $\begin{array}{l}45-54 \\
\text { years }\end{array}$ & $\begin{array}{l}55-64 \\
\text { years }\end{array}$ & $\begin{array}{l}65-74 \\
\text { years }\end{array}$ & $\begin{array}{l}75-84 \\
\text { years }\end{array}$ & $\begin{array}{l}85 \text { years } \\
\text { and older }\end{array}$ \\
\hline \multicolumn{7}{|l|}{ Mexican American ${ }^{a}$} \\
\hline Total & 8 & 48 & 187 & 552 & 944 & 1575 \\
\hline Men & 10 & 56 & 202 & 572 & 1013 & 1556 \\
\hline Women & 7 & 38 & 172 & 534 & 894 & 1586 \\
\hline \multicolumn{7}{|l|}{ Puerto Rican } \\
\hline Total & 11 & 47 & 167 & 381 & 798 & 1282 \\
\hline Men & 15 & 56 & 183 & 413 & 869 & 1163 \\
\hline Women & 7 & 40 & 153 & 357 & 756 & 1338 \\
\hline \multicolumn{7}{|l|}{ Cuban } \\
\hline Total & 6 & 17 & 60 & 188 & 405 & 792 \\
\hline Men & 8 & 22 & 67 & 236 & 449 & 730 \\
\hline Women & 4 & 12 & 53 & 147 & 377 & 820 \\
\hline
\end{tabular}

\footnotetext{
a Rates have been rounded to the nearest whole number.
}

groups. For all three Hispanic subgroups, heart disease was the underlying cause of death in approximately $31 \%$ of all diabetes-related deaths. In all three Hispanic subgroups, cancer was the underlying cause of death in $7 \%$ to $8 \%$ of all diabetes-related deaths, and stroke was the underlying cause of death in $4 \%$ to $6 \%$ of all diabetesrelated deaths.

\section{DISCUSSION}

Our study provides a substantive analysis of diabetes-related mortality in the heterogeneous Hispanic community residing in the United States. We were cognizant that although Hispanics as a whole are at higher risk for diabetes than other ethnic groups, some Hispanic subgroups may be at higher risk for diabetes mortality than others. When Hispanics are analyzed as a homogeneous group, this variation in risk for diabetes mortality is masked.

During 1996 and 1997, diabetes was the underlying or contributing cause of death for approximately 20000 Mexican Americans, Puerto Ricans, and Cuban Americans over 35 years of age in the United States. Mexican Americans were at highest risk for diabetesrelated mortality compared with other Hispanic subgroups. Mexican Americans (251 deaths per 100000$)$ and Puerto Ricans (204 deaths per 100 000) were twice as likely to die from diabetes-related conditions as Cuban Americans (101 deaths per 100 000). The heterogeneity in diabetes-related mortality rates is consistent with an earlier study by Rosenwaike of mortality differentials among Hispanics subgroups (13).

Using mortality data for individuals over 5 years of age from 1979 to 1981, Rosenwaike found that the ageadjusted diabetes death rate for Puerto Ricans was 29.6 deaths per 100 000, followed by Mexican Americans (28.8 deaths per 100 000) and Cuban Americans (14.7 deaths per 100 000). In his study, Puerto Ricans had the highest risk for diabetes mortality. However, in our study Mexican Americans and Puerto Ricans were twice as likely to 
die from diabetes as Cuban Americans. Although Rosenwaike used data from NCHS mortality tapes for the numerator and the 1980 census for the denominator to calculate age-adjusted death rates, he focused only on immigrants from Mexico, Puerto Rico and Cuba. Also, Rosenwaike's calculations included only deaths for which diabetes was recorded as the underlying cause. Our study improves on previous research by including deaths for which diabetes was a contributing cause of death.

Diabetes is a chronic condition that can go undiagnosed and untreated for a long time, eventually leading to death if an individual does not have health insurance and access to regular medical care (21). Given the important role that access to the health care system plays in preventing and effectively treating diabetes, one likely explanation for the diabetes-related mortality disparities that our study found between Mexican Americans, Puerto Ricans and Cuban Americans is socioeconomic status. Socioeconomic factors such as poverty, income, education, employment, and migration may contribute to ethnic health disparities (22).

In our study, we found that Mexican Americans and Puerto Ricans, who had the highest age-adjusted diabetesmortality rates, generally attained lower levels of education than Cuban Americans. Our findings are consistent with an NCHS survey that found that Mexican Americans and Puerto Ricans had lower educational attainments than Cuban Americans (14). This study also noted that higher percentages of Mexican Americans and Puerto Ricans had lower incomes and lived below the poverty line than Cuban Americans. Another NCHS survey found that Mexican Americans were more likely to be uninsured (39\%), followed by Cuban Americans (21\%) and Puerto Ricans (19\%) (23). As a result, Hispanic subgroups face not only cultural and language barriers to obtaining access to health care, but also socioeconomic barriers such as poverty and low educational attainment. Cuban Americans have the highest socioeconomic status among
Hispanic subgroups, which may explain why their diabetes-related mortality rates were lower than in Mexican Americans and Puerto Ricans. Thus, future research in the area of diabetes morbidity and mortality should investigate the role that socioeconomic factors play in contributing to the disparate health outcomes in different Hispanic subgroups.

Our study also found that after diabetes, heart disease $(31 \%)$, followed distantly by cancer (8\%) and stroke $(6 \%)$, were the primary underlying causes of death in all diabetes-related deaths. The finding that heart disease was often the underlying cause of death in these Hispanic subgroups is consistent with diabetes mortality research which has found that heart disease is the leading cause of death for individuals with diabetes (8). Thus, diabetes is frequently recorded as a contributing cause of death when the underlying cause of death is heart disease. The finding that cancer and stroke were also primary underlying causes of death in all diabetes-related deaths among Hispanic subgroups may be related to previous research which has shown that these diseases share many of the same risk factors, such as older age, obesity, family history of diabetes, and physical inactivity $(8,24)$. In addition, people with diabetes are twofold to fourfold more likely to suffer a stroke, which may explain why diabetes was frequently recorded as a contributing cause of death when stroke was the underlying cause of death (8).

\section{Limitations}

Some potential problems might have influenced our analysis of diabetesrelated mortality data for Mexican Americans, Puerto Ricans, and Cuban Americans. The first problem was that diabetes may frequently be underreported on death certificates. Earlier studies found that diabetes is listed as an underlying or contributing cause of death in only about $35 \%$ to $40 \%$ of the patients known to have this disease $(8,25,26)$. However, these vali- dation studies were conducted in the mid-1980s, and in more recent years health professionals have become more aware that diabetes is an important contributor to the cause of death.

A second problem is that ethnicity may be misreported on death certificates (27). The demographic information on death certificates is collected from family members or funeral directors if a family member is not available. The National Longitudinal Mortality Study, a database of Current Population Surveys (CPS) files maintained by the National Heart, Lung, and Blood Institute along with the Census Bureau and NCHS, provides data on the reliability of Hispanic origin on death certificates (28). A study that compared 12 CPS files against the Hispanic origin section as recorded on death certificates from 21 states resulted in $89.7 \%$ agreement (29). The ratio of the number of decedents in the CPS reported as Hispanic divided by the number of decedents reported as Hispanic on death certificates was 1.07 for Hispanics overall, 1.11 for Mexican Americans, 1.04 for Puerto Ricans, and 1.07 for Cuban Americans. This ratio indicates a net underreporting of Hispanic ethnicity on death certificates.

A third problem is undercounting of minority groups by the United States Bureau of the Census, a problem that can lead to underestimation of the denominator for morality rates. For the 1990 census, a postenumeration survey conducted by the United States Bureau of the Census showed that the estimated undercount of Hispanics was 5\% (30).

Consequently, misclassification of ethnicity in the numerator (deaths) biases the mortality rate downward, and underestimation of the denominator (population counts) biases the mortality rate upwards. Taken together, these two sources of bias most likely resulted in a slight underestimation of the mortality rates. A report from NCHS has estimated that correcting these problems would result in a $2 \%$ increase in mortality rates for Hispanics overall (27).

A final limitation of our study is that about 9 years have elapsed since the 
data were gathered in 1996-1997. However, our analysis makes an important contribution to the limited research on diabetes-related mortality among Hispanic subgroups in the United States. Our analysis also provides baseline figures for diabetes mortality which can be useful for comparison with more recent data, given the lack of trend line information for health outcomes among Hispanic subgroups. We recommend that these analyses be replicated and verified with more recent data. Well-designed research is needed to explore the complex cultural, socioeconomic, and biomedical factors that could explain disparities within the growing Hispanic communities of the United States.

Our analysis of diabetes-related mortality among Mexican Americans, Puerto Ricans and Cuban Americans found disparities that are often masked when Hispanics are treated as a homogeneous group rather than as a rapidly growing heterogeneous group with diverse ethnic identities and socioeconomic statuses. Awareness of this heterogeneity in diabetes-related mortality in Mexican Americans, Puerto Ricans, and Cuban Americans may help policy makers determine how public health resources should be distributed by state and local health agencies in areas where Hispanic subgroups at higher risk for diabetesrelated mortality reside. Clinicians and researchers can use our findings to develop interventions and provide treatment for diabetes that target Hispanic subgroups at higher risk for diabetes in their area.

Further research on diabetes among Hispanic subgroups should involve geographic analyses of mortality rates to identify patterns of diabetes-related mortality in these and other Hispanic subgroups on the state and local levels in the United States. Moreover, future research on health outcomes among Hispanic subgroups rather than Hispanics as an aggregate ethnic group may indicate other health disparities in addition to the diabetes mortality disparities found in our study, which will need to be addressed by policy makers and clinicians who provide health services to these diverse Hispanic subgroups.

Acknowledgments. We wish to thank Latetia Moore, M.S.P.H., Carol R. Williams, M.P.H., Beverly Ward, Ph.D., and Dinorah Martinez, M.P.H for their useful contributions to the planning and analysis of this research. Dr. Barnett was supported in part by an Established Investigator Grant from the American Heart Association.

\section{REFERENCES}

1. United States of America. United States Bureau of the Census: Overview of Race and Hispanic Origin: Census 2000 Brief. [Internet site]. Available from http://www.census. gov/prod/2001pubs/c2kbr01-1.pdf. Accessed 15 October 2004.

2. Trueba ET. Latinos unidos: from cultural diversity to the politics of solidarity. Lanham (MD): Rowman \& Littlefield; 1999.

3. Peters KD, Kochanek KD, Murphy SL. Deaths: final data for 1996. Natl Vital Stat Rep. 1998; 47(9):1-100.

4. Hoyert DL, Kochanek KD, Murphy SL. Deaths: final data for 1997. Natl Vital Stat Rep. 1999; 47(19):1-104.

5. Murphy SL. Deaths: final data for 1998. Natl Vital Stat Rep. 2000; 48(11):1-105.

6. Anderson RN. Deaths: leading causes for 1999. Natl Vital Stat Rep. 2001;49(11):1-87.

7. Centers for Disease Control and Prevention, National Center for Chronic Disease Prevention and Health Promotion. Diabetes public health resource [Internet site]. Available from http://www.cdc.gov/diabetes/ pubs/general. htm\#what. Accessed 20 October 2004.

8. United States of America, Centers for Disease Control and Prevention, National Center for Chronic Disease Prevention and Health Promotion. Diabetes public health resource [Internet site]. Available from http://www.cdc. gov/diabetes/pubs/estimates.htm\#Deaths. Accessed 20 October 2004.

9. United States of America, Centers for Disease Control and Prevention. Prevalence of diabetes among Hispanics-Selected areas, 1998-
2002. MMWR Morb Mortal Wkly Rep. 2004; 53(40):941-4.

10. United States of America, Centers for Disease Control and Prevention. Self-reported prevalence of diabetes among Hispanics-United States, 1994-1997. MMWR Morb Mortal Wkly Rep. 1999;48(1):8-12.

11. Luchsinger, AJ. Diabetes. In: Aguirre-Molina M, Molina CW, Zambrana RE, eds. Health issues in the Latino community. San Francisco: Jossey-Bass; 2001. Pp. 277-300.

12. Hunt KJ, Williams K, Resendez RG, Hazuda HP, Haffner SM, Stern MP. All-cause and cardiovascular mortality among diabetic participants in the San Antonio Heart Study: Evidence against the "Hispanic Paradox." Diabetes Care. 2002;25(9):1557-63.

13. Rosenwaike I. Mortality differentials among persons born in Cuba, Mexico, and Puerto Rico residing in the United States, 1979-81. Am J Public Health. 1987;77(5): 603-6.

14. Hajat A, Lucas JB, Kington R. Health outcomes among Hispanic subgroups: data from the national health interview survey, 1992-1995. Adv Data Vital Health Stat. 2000;310:1-14.

15. Hummer R, Rogers, RG, Amir SH, Forbes D, Frisbie, WP. Adult mortality differentials among hispanic subgroups and non-Hispanic whites. Soc Sci Q. 2000; 81(1):458-76.

16. Sorlie PD, Backlund E, Johnson NJ, Rogat E. Mortality of Hispanic status in the United States. JAMA. 1993;270(20):2464-8.

17. United States Bureau of the Census: persons of Hispanic origin in the United States: 1990 Census of Population. Washington, D.C.: United States Government Printing; 1993.
18. United States Bureau of the Census: American fact finder: Census 2000 summary file 2. [Internet site]. Available from http://factfinder. census.gov/servlet/DatasetMainPage Servlet?_ds_name=DEC_2000_SF2_U\&_ program $=$ DEC\&_lang=en. Accessed 15 October 2004.

19. United States of America, National Center for Health Statistics: National Vital Statistics System. [Internet site]. Available from http:// www.cdc.gov/nchs/about/major/dvs/mort data.htm. Accessed 18 October 2004.

20. Practice Management Information Corporation. ICD-9-CM International Classification of Diseases, 9th Revision, Clinical Modification, 2005; 2004.

21. Anonymous. Mortality health disparities experienced by Hispanics-United States. MMWR Morb Mortal Wkly Rep. 2004;53(40): 935-7.

22. Williams DR, Neighbors HW, Jackson JS. Racial/ethnic discrimination and health: findings from community studies. Am J Public Health. 2003;93:200-8.

23. Carter-Pokras O, Zambrana RE. Latino health status. In: Aguirre-Molina M, Molina CW, Zambrana RE, eds. Health issues in the Latino community. San Francisco: Jossey-Bass; 2001. Pp. 23-54.

24. United States of America, National Cancer Institute: Director's Corner. [Internet site] Available from http://www.nci.nih.gov/ directorscorner/directorsupdate-01-20-2004. Accessed 18 October 2004

25. Bild DE, Stevenson JM. Frequency of recording of diabetes on US death certificates: analy- 
sis of the 1986 National Mortality Followback Survey. J Clin Epidemiol. 1992;45(3):275-81.

26. Ochi JW, Melton LJ, Palumbo PJ, Chu-Pin C. A population-based study of diabetes mortality. Diabetes Care. 1985;8:224-9.

27. Rosenburg HM, Mauer JD, Sorlie P, Johnson NJ. Quality of death rates by race and Hispanic origin: a summary of current research, 1999. Vital Health Stat. 1999;2(128):1-20.
28. Sorlie PD, Rogot E, Johnson NJ. Validity of demographic characteristics on the death certificate. Epidemiology. 1992;3(2):181-4.

29. Rogot E, Sorlie PD, Johnson NJ, Schmitt C. A mortality study of 1.3 million persons by demographic, social and economic factors: 1979-1985 follow-up. Bethesda (MD): National Institutes of Health; 1992. (NIH publication 92-3297).
30. Hogan H. The 1990 Post-enumeration survey: operations and results. J Am Stat Assoc. 1993; 88(423):1047-60.

Manuscript received on 2 November 2004. Revised version accepted for publication on 1 September 2005.

RESUMEN Objetivos. Examinar la mortalidad relacionada con la diabetes entre mexicanoestadounidenses, puertorriqueños y cubanoestadounidenses de más de 35 años de edad en los Estados Unidos durante 1996 y 1997.

\section{La mortalidad relacionada con la diabetes en mexicanoestadounidenses, puertorriqueños y cubanoestadounidenses en los Estados Unidos}

Métodos. A partir de datos del Sistema Nacional de Estadísticas Vitales de los Estados Unidos y de los censos de 1999 y de 2000, calculamos las tasas de mortalidad relacionadas con la diabetes, ajustadas por edad y para cada grupo de edad específico, en mexicanoestadounidenses, puertorriqueños y cubanoestadounidenses de más de 35 años de edad. Se consideraron muertes relacionadas con la diabetes aquellas en las cuales la diabetes se codificó como causa de muerte subyacente o contribuyente.

Resultados. La tasa de mortalidad relacionada con la diabetes en mexicanoestadounidenses (251 muertes por cada 100000 habitantes) y en puertorriqueños (204 muertes por cada 100000$)$ fue dos veces mayor que dicha tasa en cubanoestadounidenses (101 muertes por cada 100 000). Los cubanoestadounidenses fallecidos tuvieron la mayor proporción de muertes en que la diabetes se codificó como causa subyacente (44\%). Después de la diabetes, las enfermedades cardíacas (31\%), seguidas del cáncer $(8 \%)$ y de los accidentes cerebrovasculares (6\%), fueron las principales causas de muerte subyacentes relacionadas con la diabetes en los tres grupos étnicos.

Conclusión. Los análisis de estos datos revelan diferencias en la mortalidad relacionada con la diabetes entre mexicanoestadounidenses, puertorriqueños y cubanoestadounidenses de más de 35 años de edad en los Estados Unidos. Factores socioeconómicos, tales como un bajo nivel educativo y la escasez de ingresos, posiblemente contribuyan a las discrepancias halladas entre las tasas de mortalidad de los diferentes subgrupos. Es necesario llevar a cabo más estudios para actualizar estos resultados e investigar los factores de riesgo que los explican. Se ha seguido observando gran diversidad entre diferentes subgrupos de hispanos en años recientes, factor que debe tomarse en cuenta en el desarrollo de políticas y servicios dirigidos a estas poblaciones.

Palabras clave Indicadores de salud, mortalidad, diabetes mellitus, hispanoamericanos, estadísticas, epidemiología, factores socioeconómicos. 